\title{
Evaluation of Thermodynamic Activity of a Metallic Oxide in a Ternary Slag from the Sulphide Capacity of the Slag
}

\author{
M. HAYASHI, N. SANO ${ }^{11}$ and P. FREDRIKSSON \\ Royal Institute of Technology, Department of Materials Science and Engineering, SE-10044 Stockholm, Sweden. \\ 1) Executive Advisor, Nippon Steel Corporation, Shintomi, Futtsu, Chiba 293-8511 Japan.
}

(Received on December 1, 2003; accepted in final form on August 31, 2004)

\begin{abstract}
The correlation between the activity of a metallic oxide in a ternary slag system and the sulphide capacity of the slag was investigated. The solubility of sulphur in the binary systems $\mathrm{CaO}-\mathrm{SiO}_{2}$ and $\mathrm{Al}_{2} \mathrm{O}_{3}-\mathrm{CaO}$ along with its sulphide capacity of the $\mathrm{Al}_{2} \mathrm{O}_{3}-\mathrm{CaO}-\mathrm{SiO}_{2}$ system respectively have been used to estimate the activities of $\mathrm{CaO}$ at the compositions of some $\mathrm{Al}_{2} \mathrm{O}_{3}-\mathrm{CaO}-\mathrm{SiO}_{2}$ intermediate compounds. Estimation has been carried out assuming that the Gibbs free energy of fusion for the ternary composition is additive of those for pure substances. The estimated values of the activities are in good agreement with the measured values. This correlation is not only used to evaluate the activity but also, by comparing the estimated activities with the measured ones, it is possible to elucidate the applicability of Henry's law to the activity of a metallic sulphide and to determine the order in the affinity of a cation to sulphur between two metallic oxides in a slag.
\end{abstract}

KEY WORDS: activity; sulphide capacity; sulphur solubility; slag.

\section{Introduction}

In the refining of steel, activities of slag components and sulphide capacities of slag systems are both important thermodynamic concepts. In view of the great importance of these properties, considerable efforts have been made to obtain reliable experimental data regarding these properties as well as to extrapolate the data using suitable theoretical models. It is to be noted that the relative partial molar Gibbs energy of mixing, which is equal to $R T \ln a_{\mathrm{M}_{x} \mathrm{O}}$ (where $R$ is the gas constant, $T$ the temperature and $a_{\mathrm{M}_{\mathrm{O}} \mathrm{O}}$ the thermodynamic activity of the component oxide $\mathrm{M}_{x} \mathrm{O}$ in the slag) as well as the sulphide capacity are partial molar properties of the system. In fact, the sulphide capacity of a binary silicate slag is related to the thermodynamic activity of the basic oxide in the system. Nilsson et al. ${ }^{1)}$ have shown for a number of binary oxide systems that the sulphide capacities are linear functions of the activities of the basic oxides. Similar correlations are extremely desirable for higher order systems. Development of such correlations is difficult due to the non-adherence of the sulphide activities in the complex slags to Henry's law and the uncertainty regarding the relative effects of the various metal oxides with respect to their affinities to sulphur. A successful thermodynamic exercise in correlating the sulphide capacities with thermodynamic activities will yield a sounder theoretical basis for the use of thermodynamic principles in the desulphurization process in steelmaking. This is due to the fact that, the concept of sulphide capacity itself is built on the assumption that the activity coefficient of the sulphide ion in the slag as well as the oxide ion activity are independent of the sulphur content.

However, the present attempt has a dissimilar aim. The thermophysical and thermochemical properties of slags are strongly dependent on the slag structure. Hence, it is natural to expect that these properties are interrelated. Based on this concept, considerable work has been carried out in the Division of Metallurgy, Royal Institute of Technology on relating viscosities with thermodynamic properties ${ }^{2}$ and phase diagram information, ${ }^{3)}$ and enthalpies as well as densities. ${ }^{4)}$ Establishment of such mutual correlations would enable to estimate one property from another having reliable experimental data available. In the present study, a correlation between the activity and sulphide capacity respectively was developed for ternary systems in order to evaluate the activity of the metallic oxide of ternary systems from the sulphide capacity. It is expected that this approach will pave the way for developing models for the prediction of the thermodynamic activity of slag components from the vast amount of experimental data available for the sulphide capacities of multicomponent slag systems.

\section{Basic Considerations}

The equilibrium controlling the incorporation of sulphur in a slag from the gas phase at low chemical potential of oxygen can be represented by the equation,

$$
\frac{1}{2} \mathrm{~S}_{2}(\mathrm{~g})+\left(\mathrm{O}^{2-}\right)_{\text {slag }}=\frac{1}{2} \mathrm{O}_{2}(\mathrm{~g})+\left(\mathrm{S}^{2-}\right)_{\text {slag }}
$$

The equilibrium constant for this reaction is given by, 


$$
K=\left(\frac{a_{\mathrm{S}^{2-}}}{a_{\mathrm{O}^{2-}}}\right) \cdot\left(\frac{p_{\mathrm{O}_{2}}}{p_{\mathrm{S}_{2}}}\right)^{1 / 2}=\frac{\left(x_{\mathrm{S}^{2-}} \cdot \gamma_{\mathrm{S}^{2-}}\right)}{a_{\mathrm{O}^{2-}}} \cdot\left(\frac{p_{\mathrm{O}_{2}}}{p_{\mathrm{S}_{2}}}\right)^{1 / 2}
$$

The concentration of sulphur in weight percent is written as follows:

$$
\mathrm{wt} \% \mathrm{~S}=\frac{100 x_{\mathrm{S}^{2}} M_{\mathrm{S}}}{\sum_{i} x_{i} M_{i}}
$$

where $x_{\mathrm{S}^{2-}}, M_{\mathrm{S}}, x_{i}$ and $M_{i}$ are the molecular fraction of sulphide $\left(\mathrm{M}_{x} \mathrm{~S}\right)$, the atomic weight of sulphur, and the molecular fraction and weight of component $i$, respectively. From Eqs. (2) and (3),

$$
a_{\mathrm{O}^{2-}}=\frac{\gamma_{\mathrm{S}^{2-}}}{K} \cdot \frac{\sum_{i} x_{i} M_{i}}{100 M_{\mathrm{S}}} \cdot(\mathrm{wt} \% \mathrm{~S}) \cdot\left(\frac{P_{\mathrm{O}_{2}}}{P_{\mathrm{S}_{2}}}\right)^{1 / 2}
$$

The sulphide capacity is defined by Fincham and Richardson $^{5)}$ as:

$$
C_{\mathrm{S}}=(\mathrm{wt} \% \mathrm{~S}) \cdot\left(\frac{P_{\mathrm{O}_{2}}}{P_{\mathrm{S}_{2}}}\right)^{1 / 2}
$$

By substituting Eq. (5) into Eq. (4),

$$
a_{\mathrm{O}^{2-}}=\frac{\gamma_{\mathrm{S}^{2-}}}{K} \cdot \frac{\sum_{i} x_{i} M_{i}}{100 M_{\mathrm{S}}} C_{\mathrm{S}}
$$

Since activities of $\mathrm{O}^{2-}$ and $\mathrm{S}^{2-}$ ions cannot be directly measured, Eq. (1) can be rewritten in terms of neutral molecules dissolved in the slag:

$$
\frac{1}{2} \mathrm{~S}_{2}(\mathrm{~g})+\left(\mathrm{M}_{x} \mathrm{O}\right)_{\text {slag }}=\frac{1}{2} \mathrm{O}_{2}(\mathrm{~g})+\left(\mathrm{M}_{x} \mathrm{~S}\right)_{\text {slag }}
$$

The activity of $\mathrm{M}_{x} \mathrm{O}$ can then be expressed as:

$$
a_{\mathrm{M}_{x} \mathrm{O}}=\frac{\gamma_{\mathrm{M}_{x} \mathrm{~S}}}{K} \cdot \frac{\sum_{i} x_{i} M_{i}}{100 M_{\mathrm{S}}} C_{\mathrm{S}}
$$

\section{Evaluation of $a_{\mathrm{CaO}}$ from $C_{\mathrm{s}}$ in the $\mathrm{CaO}-\mathrm{Al}_{2} \mathrm{O}_{3}-\mathrm{SiO}_{2}$ System}

In order to develop a method for evaluating the activity of the metallic oxide of ternary systems from the sulphide capacity, the $\mathrm{CaO}-\mathrm{Al}_{2} \mathrm{O}_{3}-\mathrm{SiO}_{2}$ system is considered as an example. Equations (7) and (8) can be rewritten as follows:

$$
\begin{gathered}
\frac{1}{2} \mathrm{~S}_{2}(\mathrm{~g})+\mathrm{CaO}=\frac{1}{2} \mathrm{O}_{2}(\mathrm{~g})+\mathrm{CaS} \\
a_{\mathrm{CaO}}=\frac{\gamma_{\mathrm{CaS}}}{K_{9}} \cdot \frac{\sum_{i} x_{i} M_{i}}{100 M_{\mathrm{S}}} C_{\mathrm{S}} \cdots \cdots . . .
\end{gathered}
$$

The standard Gibbs energy change for Eq. (9) is ${ }^{6)}$ :

$$
\Delta G_{9}^{\circ}=-R T \ln K_{9}=92048-4.73 T \quad(\mathrm{~J} / \mathrm{mol})
$$

To evaluate the value of $a_{\mathrm{CaO}}$ from the sulphide capacity by using Eq. (10), the value of $\gamma_{\mathrm{CaS}}$ at a ternary composition is
Table 1. Standard free-energy data for intermediate compounds. $\left.{ }^{6}\right)$

\begin{tabular}{l|l|l}
\hline Reaction & $\Delta H^{\circ}(\mathrm{J} /$ mole $)$ & $\Delta S^{\circ}(\mathrm{J} /$ mole $)$ \\
\hline$<3 \mathrm{CaO} \cdot \mathrm{Al}_{2} \mathrm{O}_{3}>=3<\mathrm{CaO}>+<\mathrm{Al}_{2} \mathrm{O}_{3}>$ & 12550 & -24.7 \\
\hline$<\mathrm{CaO} \cdot \mathrm{Al}_{2} \mathrm{O}_{3}>=<\mathrm{CaO}>+<\mathrm{Al}_{2} \mathrm{O}_{3}>$ & 17990 & -18.8 \\
\hline$<\mathrm{CaO} \cdot \mathrm{SiO}_{2}>=<\mathrm{CaO}>+<\mathrm{SiO}_{2}>$ & 92470 & 2.5 \\
\hline$<3 \mathrm{CaO} \cdot \mathrm{Al}_{2} \mathrm{O}_{3} \cdot 3 \mathrm{SiO}_{2}>=3<\mathrm{CaO}>+<\mathrm{Al}_{2} \mathrm{O}_{3}>+3<\mathrm{SiO}_{2}>$ & 384930 & 100.4 \\
\hline$<2 \mathrm{CaO} \cdot \mathrm{Al}_{2} \mathrm{O}_{3} \cdot \mathrm{SiO}_{2}>=2<\mathrm{CaO}>+<\mathrm{Al}_{2} \mathrm{O}_{3}>+<\mathrm{SiO}_{2}>$ & 171130 & 8.8 \\
\hline$<\mathrm{CaO} \cdot \mathrm{Al}_{2} \mathrm{O}_{3} \cdot \mathrm{SiO}_{2}>=<\mathrm{CaO}>+<\mathrm{Al}_{2} \mathrm{O}_{3}>+<\mathrm{SiO}_{2}>$ & 105860 & 14.2 \\
\hline$<\mathrm{CaO} \cdot \mathrm{Al}_{2} \mathrm{O}_{3} \cdot 2 \mathrm{SiO}_{2}>=<\mathrm{CaO}>+<\mathrm{Al}_{2} \mathrm{O}_{3}>+2<\mathrm{SiO}_{2}>$ & 138910 & 17.2
\end{tabular}

required.

When a ternary composition is containing substances 1 and 2 besides $\mathrm{CaO}$ and, the activity coefficients of $\mathrm{CaS}$ in $\mathrm{CaO}-1$, and $\mathrm{CaO}-2$ binary systems are known, the value of $\gamma_{\mathrm{CaS}}$ at the ternary composition can be calculated by using the activity coefficients in $\mathrm{CaS}$ for the two binary systems, i.e., $\gamma_{\mathrm{CaS}, 1}$ and $\gamma_{\mathrm{CaS}, 2}$ by employing the following equation, ${ }^{7)}$

$$
\ln \gamma_{\mathrm{CaS}}=x_{1} \ln \gamma_{\mathrm{CaS}, 1}+x_{2} \ln \gamma_{\mathrm{CaS}, 2}-\frac{\Delta G_{1}^{\mathrm{E}}}{R T}
$$

where $\Delta G_{1}^{\mathrm{E}}$ is the excess Gibbs free energy of mixing for the liquid state, and $x_{1}$ and $x_{2}$ are the mole fractions of substances 1 and 2 respectively. The values of $\gamma_{\mathrm{CaS}}$ in the binary systems $\mathrm{CaO}-\mathrm{SiO}_{2}$ and $\mathrm{CaO}-\mathrm{Al}_{2} \mathrm{O}_{3}$ were obtained by employing data on the $\mathrm{CaS}$ solubilities in the $\mathrm{CaO}-\mathrm{SiO}_{2}-\mathrm{CaS}$ and $\mathrm{CaO}-\mathrm{Al}_{2} \mathrm{O}_{3}-\mathrm{CaS}$ systems ${ }^{8)}$ assuming that the activities of $\mathrm{CaS}$ in these systems obey Henry's law. This is, $\gamma_{\mathrm{CaS}}=1 / x_{\mathrm{CaS}}^{\circ}$ where $x_{\mathrm{CaS}}^{\circ}$ is the CaS solubility. For Eq. (12), the value of $\Delta G_{1}^{\mathrm{E}}$ is required. The excess Gibbs free energy of mixing for the liquid state, $\Delta G_{1}^{\mathrm{E}}$, required in Eq. (12) is:

$$
\Delta G_{1}^{\mathrm{E}}=\Delta G_{1}^{\mathrm{M}}-R T\left(x_{1} \ln x_{1}+x_{2} \ln x_{2}\right)
$$

where $\Delta G_{1}^{\mathrm{M}}$ is the Gibbs free energy of mixing for the liquid state. $\Delta G_{1}^{\mathrm{M}}$ is correlated with the Gibbs free energy of mixing for the solid state $\Delta G_{\mathrm{s}}^{\mathrm{M}}$ as follows:

$$
\Delta G_{1}^{\mathrm{M}}=\Delta G_{\mathrm{s}}^{\mathrm{M}}+\Delta G_{\mathrm{m}}-\left(x_{1} \Delta G_{1 \mathrm{~m}}^{\circ}+x_{2} \Delta G_{2 \mathrm{~m}}^{\circ}\right)
$$

where $\Delta G_{\mathrm{m}}, \Delta G_{1 \mathrm{~m}}^{\circ}$ and $\Delta G_{2 \mathrm{~m}}^{\circ}$ are the Gibbs free energy of fusion for the ternary composition and the pure substances 1 and 2, respectively. If the following additivity rule is assumed,

$$
\Delta G_{\mathrm{m}}=x_{1} \Delta G_{1 \mathrm{~m}}^{\circ}+x_{2} \Delta G_{2 \mathrm{~m}}^{\circ}
$$

then

$$
\Delta G_{1}^{\mathrm{M}}=\Delta G_{\mathrm{s}}^{\mathrm{M}}
$$

The values of $\Delta G^{\circ}$ for the formation of the intermediate compounds $\mathrm{CaO}-\mathrm{Al}_{2} \mathrm{O}_{3}, \mathrm{CaO}-\mathrm{SiO}_{2}, 3 \mathrm{CaO}-\mathrm{Al}_{2} \mathrm{O}_{3}, 2 \mathrm{CaO}-$ $\mathrm{Al}_{2} \mathrm{O}_{3}-\mathrm{SiO}_{2}, \mathrm{CaO}-\mathrm{Al}_{2} \mathrm{O}_{3}-2 \mathrm{SiO}_{2}, \mathrm{CaO}-\mathrm{Al}_{2} \mathrm{O}_{3}-\mathrm{SiO}_{2}$ and $3 \mathrm{CaO}-\mathrm{Al}_{2} \mathrm{O}_{3}-3 \mathrm{SiO}_{2}$ from $\mathrm{CaO}, \mathrm{Al}_{2} \mathrm{O}_{3}$ and/or $\mathrm{SiO}_{2}$ respectively presented in Table 1 were taken from the compilation of Turkdogan. $\left.{ }^{6}\right)$ These compounds correspond to the points a, b, c, I, II, III and IV respectively in Fig. $\mathbf{1}$ and $(1 / 2)\left(\mathrm{CaO} \cdot \mathrm{Al}_{2} \mathrm{O}_{3}\right),(1 / 2)\left(\mathrm{CaO} \cdot \mathrm{SiO}_{2}\right),(1 / 4)\left(3 \mathrm{CaO} \cdot \mathrm{Al}_{2} \mathrm{O}_{3}\right)$, $(1 / 4)\left(2 \mathrm{CaO} \cdot \mathrm{Al}_{2} \mathrm{O}_{3}-\mathrm{SiO}_{2}\right),(1 / 4)\left(\mathrm{CaO} \cdot \mathrm{Al}_{2} \mathrm{O}_{3} \cdot 2 \mathrm{SiO}_{2}\right),(1 / 3)$ $\times\left(\mathrm{CaO} \cdot \mathrm{Al}_{2} \mathrm{O}_{3} \cdot \mathrm{SiO}_{2}\right)$, and $(1 / 7)\left(3 \mathrm{CaO} \cdot \mathrm{Al}_{2} \mathrm{O}_{3} \cdot 3 \mathrm{SiO}_{2}\right)$ are abbreviated as a, b, c, I, II, III and IV, respectively. Therefore, the values of $\Delta G_{1}^{\mathrm{M}}$ and $\Delta G_{1}^{\mathrm{E}}$ for the following five reactions can be calculated by using Eqs. (15) and (13). 


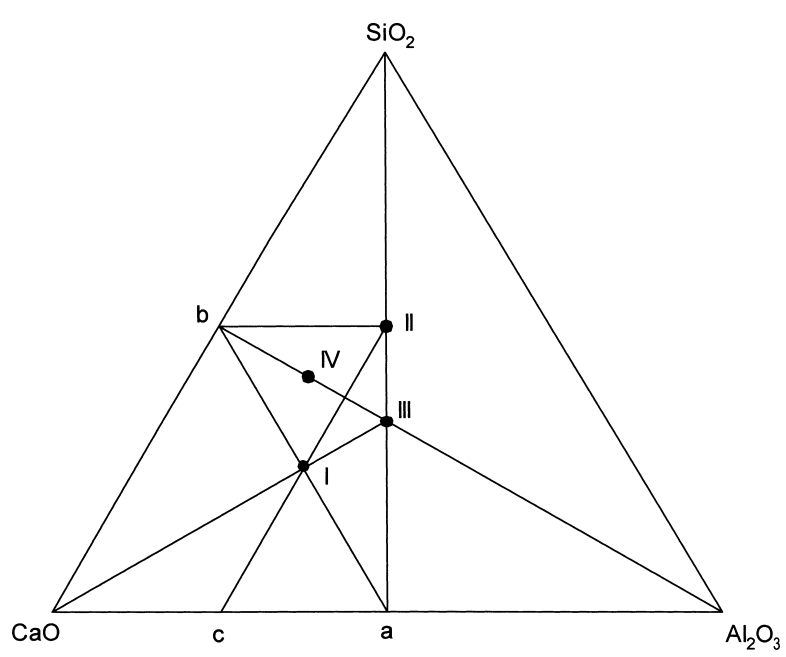

Fig. 1. Compositions on which $a_{\mathrm{CaO}}$ was determined in the $\mathrm{Al}_{2} \mathrm{O}_{3}-\mathrm{CaO}-\mathrm{SiO}_{2}$ system.

Table 2. Values of $\Delta G_{1}^{\mathrm{M}}$ and $\Delta G_{1}^{\mathrm{E}}$ at $1773 \mathrm{~K}$ for the five reactions.

\begin{tabular}{l|l|l}
\hline Reaction & $\Delta G_{l}^{M} /(\mathrm{J} /$ mole $)$ & $\Delta G_{l}^{E} /(\mathrm{J} /$ mole $)$ \\
\hline$\frac{1}{2} a+\frac{1}{2} b=I$ & -4042 & 6192 \\
\hline$\frac{1}{2} c+\frac{1}{2} I I=I$ & -18284 & -8075 \\
\hline$\frac{1}{3} a+\frac{2}{3} I I=I I I$ & -233.0 & \\
\hline$\frac{4}{7} b+\frac{3}{7} I I I=I V$ & 6569 & 9163 \\
\hline$\frac{2}{7} I+\frac{2}{7} I I+\frac{3}{7} b=I V$ & 7615 & 16652 \\
\hline
\end{tabular}

Table 3. Values of $\gamma_{\mathrm{CaS}}$ and $C_{\mathrm{s}}$ and calculated and measured values of $a_{\mathrm{CaO}}$.

\begin{tabular}{l|l|l|l|l}
\hline Compound & $\gamma_{\text {Cas }}$ & Log Cs & $a_{\text {CaO }}($ calc. $)$ & $a_{\mathrm{CaO}}(\text { meas. })^{10)}$ \\
\hline I & 25.0 & -3.46 & 0.054 & 0.03 \\
\hline II & 10.4 & -4.93 & 0.00078 & 0.001 \\
\hline III & 12.7 & -4.37 & 0.0035 & 0.002 \\
\hline IV & 3.97 & -3.94 & 0.0026 & 0.005 \\
& 2.88 & & 0.0019 & \\
\hline
\end{tabular}

$$
\begin{array}{r}
\frac{1}{2} a+\frac{1}{2} b=\text { I } \ldots \ldots . \\
\frac{1}{2} c+\frac{1}{2} \text { II }=\text { I I.... } \\
\frac{1}{3} a+\frac{2}{3} \text { II }=\text { III ..... } \\
\frac{4}{7} b+\frac{3}{7} \text { III }=\text { IV .... } \\
\frac{2}{7} \mathrm{I}+\frac{2}{7} \text { II }+\frac{3}{7} b=\text { IV }
\end{array}
$$

The values at $1773 \mathrm{~K}$ are summarized in Table 2 . Since $\gamma_{\mathrm{CaS}}$ for the binaries compounds $\mathrm{a}, \mathrm{b}$ and c respectively is obtained as 120, 12 and $20,{ }^{8}$ and assuming that the activity of CaS obeys Henry's law, the $\gamma_{\mathrm{CaS}}$ at the ternary compositions I, II, III and IV can be calculated by Eq. (12) where Eq. (20) was used to check the consistency of the calcula-

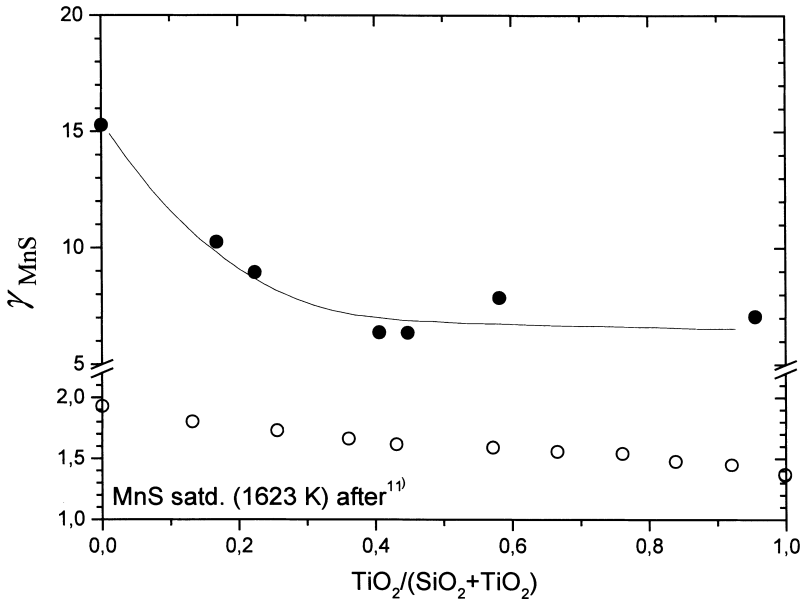

Fig. 2. Comparison of the activity coefficient of $\mathrm{MnS}$ calculated from the data of $C_{\mathrm{s}}$ and $a_{\mathrm{MnO}}$ and the one obtained from the MnS solubility, ${ }^{11)}$ which are denoted by closed and open circles, respectively.

tions. By using information of the $C_{\mathrm{s}}{ }^{9)}$ along with the values presented above, the activity of $\mathrm{CaO}$ can be calculated by using the relationship presented in Eq. (10). Comparison between the calculated and the measured values ${ }^{10)}$ respectively are found in Table 3. The agreement is reasonable, considering the above made assumptions and the accuracies of the experimental measurements for $a_{\mathrm{CaO}}$ and $C_{\mathrm{s}}$.

\section{4. $\gamma_{\mathrm{MnS}}$ in the $\mathrm{MnO}-\mathrm{SiO}_{2}-\mathrm{TiO}_{2}$ System}

To evaluate the activity of a metallic oxide in a slag system from the sulphide capacity of the slag using Eq. (8), the activity coefficient of the metallic sulphide is required. To deduce the activity coefficient of the sulphide from the solubility of the same, it is assumed that the activity of sulphide obeys Henry's law. This assumption is in the following section examined for the $\mathrm{MnO}-\mathrm{SiO}_{2}-\mathrm{TiO}_{2}$ system. Figure 2 shows a comparison of the activity coefficient of $\mathrm{MnS}, \gamma_{\mathrm{MnS}}$, calculated from the data of $C_{\mathrm{s}}$ and $a_{\mathrm{MnO}}$ by using Eq. (8) and the one obtained from the MnS solubility $^{11)}$ using the relation $\gamma_{\mathrm{MnS}}=1 / x_{\mathrm{MnS}}^{\circ}$ where $x_{\mathrm{MnS}}^{\circ}$ is the solubility for the $\mathrm{MnO}-\mathrm{SiO}_{2}-\mathrm{TiO}_{2}$ system. ${ }^{12)}$ It can be seen that the values of $\gamma_{\mathrm{MnS}}$ obtained from the MnS solubility are 1 to 5 times smaller than the ones calculated from the data of $C_{\mathrm{s}}$ and $a_{\mathrm{MnO}}$ by employing Eq. (8). This result indicates that Henry's law does not hold because $x_{\mathrm{MnS}}^{\circ}$ is very high ranging from 53 to $73 \mathrm{wt} \%{ }^{11)}$ Consequently, it is concluded that evaluation of $a_{\mathrm{MnS}}$ from $C_{\mathrm{s}}$ using Eq. (8) makes a large error in this system.

\section{Relationship between $a_{\mathrm{O}^{2-}}$ and $C_{\mathrm{s}}$ for Slags Contain- ing Two Metallic Oxides}

Although this evaluation method is only available for the slags containing one metallic oxide, it is interesting to consider the relationship between the activity of a metallic oxide and the sulphide capacity of a slag system containing two metallic oxides by using Eq. (6). Figure 3 shows the relationship between $C_{\mathrm{s}}$ and $a_{\mathrm{MnO}}$ for the $\mathrm{MnO}-\mathrm{SiO}_{2}$ system and $\mathrm{BaO}-\mathrm{MnO}-\mathrm{SiO}_{2}$ system at low $\mathrm{BaO}$ content. ${ }^{13)}$

When $\log C_{\mathrm{s}}$ is plotted against $\log a_{\mathrm{MnO}}$, a straight line 


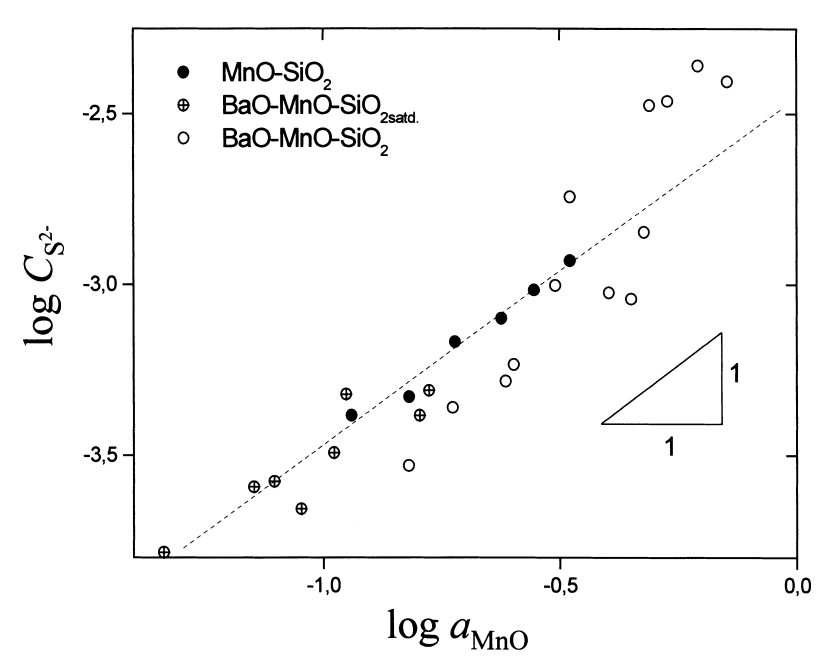

Fig. 3. Relationship between $\log C_{\mathrm{s}}$ and $\log a_{\mathrm{MnO}}$ for the $\mathrm{MnO}-\mathrm{SiO}_{2}$ system and $\mathrm{BaO}-\mathrm{MnO}-\mathrm{SiO}_{2}$ system at low $\mathrm{BaO}$ content. ${ }^{13)}$

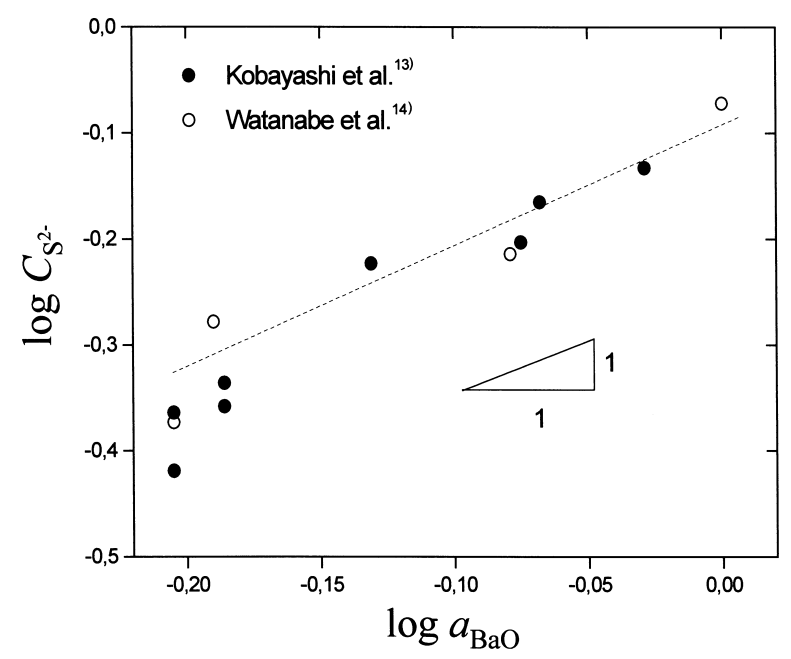

Fig. 4. Relationship between $\log C_{\mathrm{s}}$ and $\log a_{\mathrm{BaO}}$ for the $\mathrm{BaO}-\mathrm{MnO}$ system. ${ }^{13,14)}$

appears with a slope of unity for higher $\mathrm{SiO}_{2}$ content of the $\mathrm{BaO}-\mathrm{MnO}-\mathrm{SiO}_{2}$ system and the $\mathrm{MnO}-\mathrm{SiO}_{2}$ system as shown in Fig 3. Since Eq. (6) is rewritten as

$$
\log a_{\mathrm{O}^{2-}}=\log C_{\mathrm{S}}+\log \frac{\gamma_{\mathrm{S}^{2-}}}{K} \cdot \frac{\sum x_{i} M_{i}}{100 M_{\mathrm{S}}}
$$

this relationship reflects that the second term of the right hand side in Eq. (21) should be constant over the entire composition range of the $\mathrm{MnO}-\mathrm{SiO}_{2}$ and $\mathrm{BaO}-\mathrm{MnO}-\mathrm{SiO}_{2}$ systems respectively. ${ }^{13)}$ At higher $\mathrm{BaO}$ range, however, a straight line may not be drawn as shown in Fig. 3, suggesting that $a_{\mathrm{O}^{2-}}$ is not proportional to $a_{\mathrm{MnO}}$ but is affected by $\mathrm{BaO}$. Figure 4 illustrates the relationship between $C_{\mathrm{s}}$ and $a_{\mathrm{BaO}}$ for the $\mathrm{BaO}-\mathrm{MnO}$ system $^{13,14)}$ where $\mathrm{BaO}$ is considered to be more basic than MnO. It is found that the plot of $\log C_{\mathrm{s}} v s . \log a_{\mathrm{BaO}}$ yields a straight line having a slope of unity. This clearly indicates that $a_{\mathrm{BaO}}$ rather than $a_{\mathrm{MnO}}$ is closely related with $a_{\mathrm{O}^{2-}}$.

\section{Summary and Conclusions}

The correlation between the activity and sulphide capacity was developed for ternary systems. A method to evaluate the activity of a metallic oxide of a ternary slag system from the sulphide capacity of the same is presented. For this method, the activity coefficient of the metallic sulphide is required. The activity of $\mathrm{CaO}$ at some compositions in the $\mathrm{CaO}-\mathrm{Al}_{2} \mathrm{O}_{3}-\mathrm{SiO}_{2}$ ternary system was successfully evaluated from the sulphide capacity data and the activity coefficient of $\mathrm{CaS}$ in the $\mathrm{CaO}-\mathrm{SiO}_{2}$ and $\mathrm{CaO}-\mathrm{Al}_{2} \mathrm{O}_{3}$ binary systems assuming that the Gibbs free energy of fusion for the ternary composition is additive of those for pure substances. The activity coefficients of $\mathrm{CaS}$ were obtained from the solubility of $\mathrm{CaS}$ assuming that the activity of $\mathrm{CaS}$ obeys Henry's law. Although the activity coefficient of the metallic sulphide is required in this method and was obtained from the solubility of the same, the solubility of metallic sulphides have been measured in few cases and some values may be too large to assume Henry's law. This limits extension of this evaluation method at this stage.

\section{Acknowledgements}

Support from the Swedish Foundation for International Cooperation in Research and Higher Education, STINT are gratefully acknowledged. The authors would also like to acknowledge Professor Seshadri Seetharaman, division of Metallurgy, The Royal Institute of Technology, Sweden for valuable comments, suggestions and fruitful discussions.

\section{REFERENCES}

1) R. Nilsson, S. Seetharaman and K. T. Jacob: ISIJ Int., 34 (1994), No. 11,876 .

2) S. Seetharaman, D. Sichen and F. Z. Ji: Metall. Mater. Trans. B, 31B, (2000), No. 1, 105.

3) S. Seetharaman, S. Sridhar, Du Sichen and K. C. Mills: Metall. Mater. Trans. B, 31B (2000), No. 1, 111.

4) R. E. Aune, M. Hayashi and S. Sridhar: Proc. 7th Int. Conf. on Molten Slags, Fluxes and Salts, The South African Institute of Mining and Metallurgy, Johanesburg, Republic of South Africa, (2004), 517.

5) C. J. B. Fincham and F. D. Richardson: Proc. R. Soc. (London), A223 (1954), 40.

6) E. T. Turkdogan: Physical Chemistry of High Temperature Technology, Academic Press, New York, (1980), 7.

7) F. D. Richardson: Physical Chemistry of Melts in Metallurgy, Vol. 1, Academic Press, New York, (1974), 146.

8) Slag Atlas, 2nd ed., ed. by Verein Deutscher Eisenhüttenleute (VDEh), Verlag Stahleisen GmbH, Düsseldorf, (1995), 206, 208, 266.

9) M. M. Nzotta, D. Sichen and S. Seetharaman: ISIJ Int., 38 (1998), No. 11,1170

10) K. Kume, K. Morita, T. Miki and N. Sano: ISIJ Int., 40 (2000), No. 6, 561.

11) N. Koyama, F. Tsukihashi and N. Sano: Tetsu-to-Hagané, 79 (1993) No. $12,1334$.

12) M. Ito, K. Morita and N. Sano: ISIJ Int., 37 (1997), No. 9. 839.

13) T. Kobayashi, K. Morita and N. Sano: Metall. Mater. Trans. B, 27B, (1996), No. 4, 652.

14) Y. Watanabe, K. Kitamura, I. P. Rachev, F. Tsukihashi and N. Sano: Metall. Mater. Trans. B, 24B (1993), No. 2, 339. 